Please share your stories about how Open Access to this article benefits you.

\title{
Fossil fungi with suggested affinities to the Endogonaceae from the Middle Triassic of Antarctica
}

\author{
by Michael Krings. Thomas N. Taylor, \\ Nora Dotzler, and Gianna Persichini \\ 2012
}

This is the published version of the article, made available with the permission of the publisher. The original published version can be found at the link below.

[Citation]

Published version: http://www.dx.doi.org/10.3852/11-384

Terms of Use: http://www2.ku.edu/ scholar/docs/license.shtml 
Mycologia, 104(4), 2012, pp. 835-844. DOI: 10.3852/11-384

(C) 2012 by The Mycological Society of America, Lawrence, KS 66044-8897

\section{Fossil fungi with suggested affinities to the Endogonaceae from the Middle Triassic of Antarctica}

Michael Krings ${ }^{1}$

Department für Geo- und Umweltwissenschaften, Paläontologie und Geobiologie, Ludwig-MaximiliansUniversität, and Bayerische Staatssammlung für Paläontologie und Geologie, Richard-Wagner-Straße 10, 80333 Munich, Germany, and Department of Ecology and Evolutionary Biology, and Natural History Museum and Biodiversity Research Institute, University of Kansas, Lawrence, Kansas 66045

Thomas N. Taylor

Department of Ecology and Evolutionary Biology, and Natural History Museum and Biodiversity Research Institute, University of Kansas, Lawrence, Kansas 66045

Nora Dotzler

Gianna Persichini

Department für Geo- und Umweltwissenschaften, Paläontologie und Geobiologie, Ludwig-MaximiliansUniversität, Richard-Wagner-Straße 10, 80333 Munich, Germany

Abstract: Documented fossil evidence of zygomycetous fungi is rare. A conspicuous fungal fossil, Jimwhitea circumtecta gen. et sp. nov., occurs in permineralized peat from the Middle Triassic of Antarctica. The fossil is interpreted as a mantled zygosporangium that buds from a macrogametangium subtended by a sac-like macrosuspensor. The macrogametangium is united at its tip with a microgametangium which is subtended by a microsuspensor. This configuration is strikingly similar to the zygosporangium-gametangia complexes seen in certain modern Endogonaceae. Co-occurring with $J$. circumtecta are isolated propagules closely resembling the zygosporangium of $J$. circumtecta and a portion of a sporocarp containing zygosporangia embedded in a gleba. Several of the sporangia are borne on ovoid or elongate structures, which we interpret as gametangia. These fossils offer an exceptionally detailed view of the morphology and reproductive biology of early Mesozoic zygomycetes.

Key words: Endogone, Fremouw Formation, gametangium, hyphal mantle, Jimwhitea circumtecta, permineralized peat, sporocarp, zygosporangium

Submitted 17 Nov 2011; accepted for publication 10 Jan 2012.

${ }^{1}$ Corresponding author. E-mail: m.krings@1rz.uni-muenchen.de

\section{INTRODUCTION}

Documenting the evolutionary history of fungi based on fossils is generally hampered by the incompleteness of the fungal fossil record (Taylor et al. 2011). Only a few geologic deposits have yielded fungal fossils preserved in sufficient detail to permit assignment to any one of the major lineages of fungi with any degree of confidence. Perhaps the most famous of these deposits is the Lower Devonian (ca. 410000000 y ago) Rhynie chert, which has been instrumental in our conception of fungi in early continental ecosystems (Taylor et al. 2004). Other well preserved fungi occur in Carboniferous (359000 000-299000000 y ago) chert and coal balls (e.g. Taylor et al. 1994, 2005; Krings et al. 2007, 2009, 2010, 2011; Dotzler et al. 2011), as well as in Triassic (251000 000-199000 000 y ago) permineralized peat from Antarctica (e.g. Stubblefield et al. 1987, White and Taylor 1988, Osborn and Taylor 1989, Taylor and White 1989, Phipps and Taylor 1996, Schwendemann et al. 2011).

The record of fungi from Triassic peat deposits in Antarctica includes several types of sporocarps and isolated sporangia/spores that have been suggested as belonging to the zygomycetous fungi, order Endogonales. This assignment is based on sporocarp and/or spore size, the presence of a hyphal mantle and/or structures interpreted as suspensor cells or gametangia (Taylor and White 1989; White and Taylor 1989, 1991). These fossils are especially significant because documented fossil evidence of zygomycetes is exceedingly rare (Taylor et al. 2009). However, at the time these fossils were described, the Endogonales also still included the fungi that today are accommodated in the Glomeromycota (Morton and Benny 1990, Schüßler et al. 2001, White et al. 2006). Most of the fossils described and illustrated by Taylor and White (1989) and White and Taylor $(1989,1991)$ do not display the sexual stage of the life cycle (i.e. zygosporogenesis following gametangial fusion; see Benjamin 1979, Benny et al. 2001) in sufficient clarity to allow assignment to the Endogonales with confidence as currently interpreted. As a result, more completely preserved specimens are needed to accurately assess the fossil record of Endogonales from the Triassic of Antarctica.

This paper describes Jimwhitea circumtecta gen. et sp. nov., a newly discovered fungus from the Middle Triassic (245000 000-228000000 y ago) Fremouw Formation in the central Transantarctic Mountains 
that is interpreted as a mantled zygosporangium budding from a macrogametangium, which is fused at the tip with a microgametangium. The fossil is strikingly similar to the zygosporangium-gametangia complexes in certain modern Endogonaceae (Endogonales). Co-occurring with J. circumtecta in the rock matrix are isolated propagules that are very similar to the zygosporangium of $J$. circumtecta, as well as part of a sporocarp containing several zygosporangia attached to gametangia. The discovery of these fossils is important because they substantiate the hypothesis that at least some of the fossils described by Taylor and White (1989), and White and Taylor (1989, 1991) are in fact endogonalean sexual reproductive structures. Moreover, these fossils provide important evidence needed to discuss the evolution of certain life cycle stages in zygomycetous fungi.

\section{MATERIALS AND METHODS}

The fossils occur in permineralized peat from the Fremouw Formation in the central Transantarctic Mountains. The Fremouw Formation is a $620-750 \mathrm{~m}$ thick sequence that was deposited by low sinuosity, braided streams (Barrett et al. 1986). Permineralized peat is found at a single locality, approximately $30 \mathrm{~m}$ below the top of the formation. Blocks of permineralized peat likely were rafted into their current position during a flood that caused them to be stranded on sand bars (Taylor et al. 1989). The silica source for the permineralization was the dissolution of siliceous, volcanic detritus that was abundant in the Upper Fremouw Formation. The peat block containing the fungal remains was collected from a saddle north of Fremouw Peak in the Queen Alexandra Range of the Transantarctic Mountains (Barrett and Elliot 1973). The peat has been dated as early Middle Triassic based on palynomorphs and nearby vertebrate fossils (Farabee et al. 1990, Hammer et al. 1990).

The fossils were identified in series of eight thin sections, each approximately $100 \mu \mathrm{m}$ thick, prepared from a single block of permineralized peat $(\sim 4.5 \times 3.0 \times 2.5 \mathrm{~cm})$ by cementing thin wafers of the block to glass slides and grinding the wafers with silicon carbide powder until the rock slice is sufficiently thin to transmit light. Slides are deposited in the Paleobotany Division, Natural History Museum and Biodiversity Institute, University of Kansas, Lawrence, Kansas, under acquisition numbers 26593 26600. The slides were analyzed with normal transmitted light microscopy equipment; digital images were captured with a Leica DFC-480 camera.

\section{TAXONOMY}

Zygomycetous fungi

Subphylum Mucoromycotina Benny

Order Endogonales Moreau ex R.K. Benj.

Family Endogonaceae Paol. emend J.B. Morton et Benny
Jimwhitea M. Krings et T.N. Taylor, gen. nov. MycoBank MB563662

Fossil zygomycetous sexual reproductive structure (zygosporangium-gametangia complex); zygosporangium with hyphal mantle; gametangia apposed, differentiated (macrogametangium and macrosuspensor distinctly larger than microgametangium and microsuspensor), fused at their tips; zygosporangium budding from macrogametangium.

Type species. Jimwhitea circumtecta M. Krings et T.N. Taylor (this paper).

Etymology. Jimwhitea is proposed in honor of Dr James (Jim) F. White Jr, Rutgers University, New Brunswick, New Jersey, for his contributions to our understanding of the biodiversity of Triassic fungi from Antarctica; circumtecta (Lat.: circumtectus, - $a$, -um $=$ covered round about) refers to the hyphal mantle sheathing the zygosporangium.

Jimwhitea circumtecta M. Krings et T.N. Taylor, sp. nov. FIG. 1A-C MycoBank MB563663

Zygosporangium globose to subglobose to broadly ellipsoid, (60-)70-90 $\mu \mathrm{m}$ diam (including mantle), with prominent, one-layered mantle (up to $20 \mu \mathrm{m}$ thick) of irregularly swollen, tightly interlaced, aseptate hyphae; zygosporangium wall recognizable as narrow dark line extending along inner surface of mantle; gametangia arising from meshwork of irregularly swollen, tightly interlaced hyphae (gleba); macrogametangium thin-walled, separated from inflated, sac-like macrosuspensor by septum; microgametangium less than half the size of macrogametangium, subtended by hypha-like microsuspensor.

Holotype. Specimen (illustrated in FIG. 1A, left side of image; slide 26594) deposited in the Paleobotany Division, Natural History Museum and Biodiversity Institute, University of Kansas, Lawrence, Kansas.

Collection locality. Fremouw Peak, Queen Alexandra Range of the central Transantarctic Mountains, Antarctica $\left(84^{\circ} 17^{\prime} 41^{\prime \prime} \mathrm{S}, 164^{\circ} 21^{\prime} 48^{\prime \prime} \mathrm{E}\right)$.

Stratigraphic position. Fremouw Formation, Beacon Supergroup.

Age. Middle Triassic.

Comment. The sporangia/spores contained in the sporocarp portion (illustrated in FIG. 2) are structurally similar to the zygosporangium of J. circumtecta (see Discussion below). However, we refrain from formally including this fossil in J. circumtecta because we cannot rule out that the sporocarp was produced by a morphologically similar but different species.

\section{RESULTS}

Jimwhitea circumtecta (FIG. 1A, upper left, B, C) occurs in an area of the chert block where plant debris is infrequent and the matrix is relatively translucent; as a result, even the finest details of the 


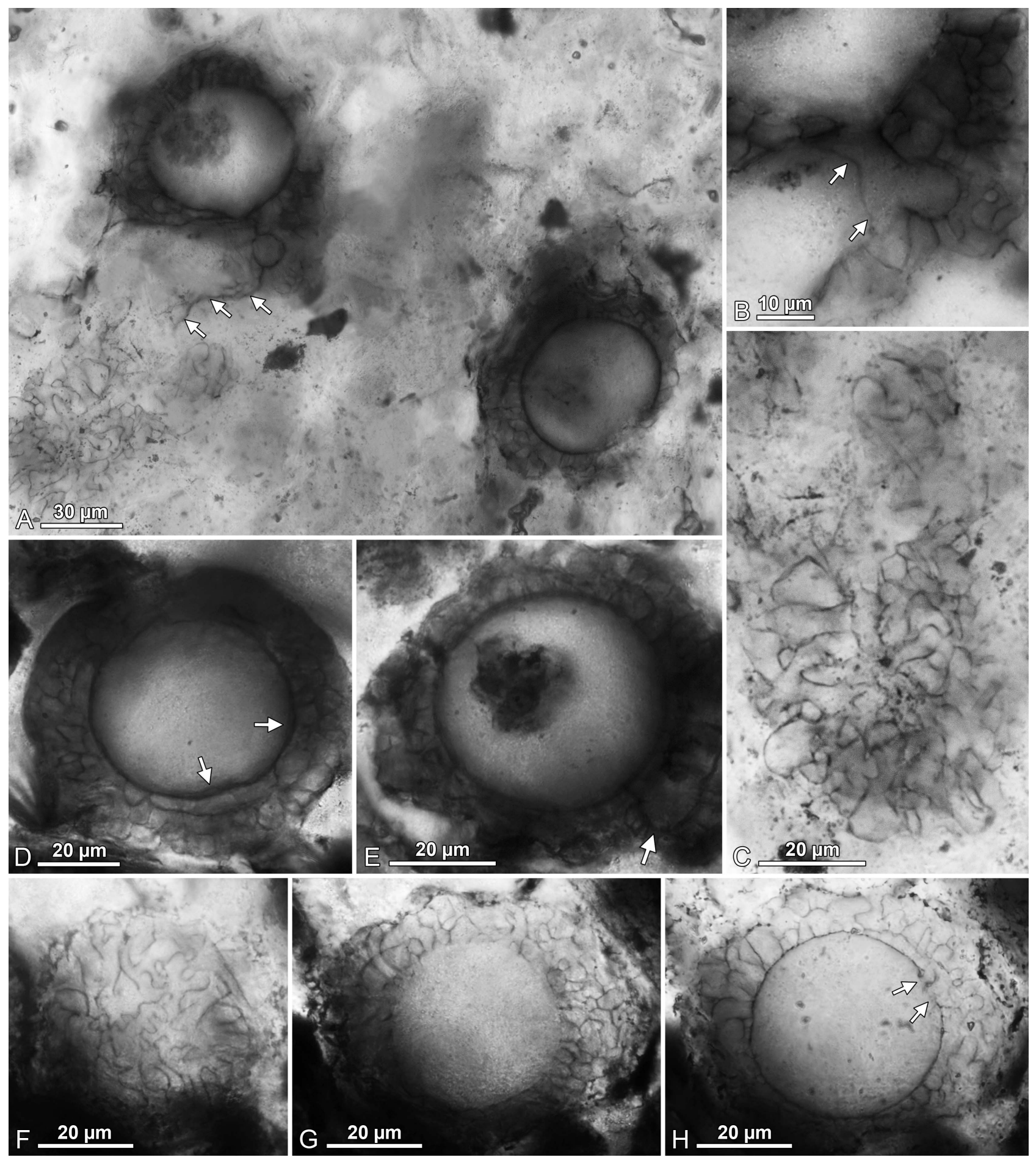

FIG. 1. A-H. Jimwhitea circumtecta gen. et sp. nov., a fossil member in the Endogonaceae from the Middle Triassic of Antarctica. A. Holotype specimen (upper left; arrows indicate sac-like macrosuspensor), associated hyphal meshwork (lower left), and second zygosporangium (lower right of image). B. Detail of a portion of A (different focal plane), showing basal region of zygosporangium budding from macrogametangium and attachment of microgametangium; arrows indicate concave septum between macrogametangium and suspensor. C. Detail of specimen in A, focusing on region of tightly interlaced hyphae (gleba). D, E. Isolated mantled zygosporangia; arrows in D indicate remnants of second wall or wall layer, while arrow in E indicates gametangium. F-H. Organization of hyphal mantle (surface and section views of one zygosporangium); arrows in $\mathrm{H}$ indicate what is interpreted as budding point from gametangium. Slide numbers: A-C: 26 594, D: 26 598, E: 26 597, F-H: 26600 (Paleobotany Division, Natural History Museum and Biodiversity Institute, University of Kansas, Lawrence). 


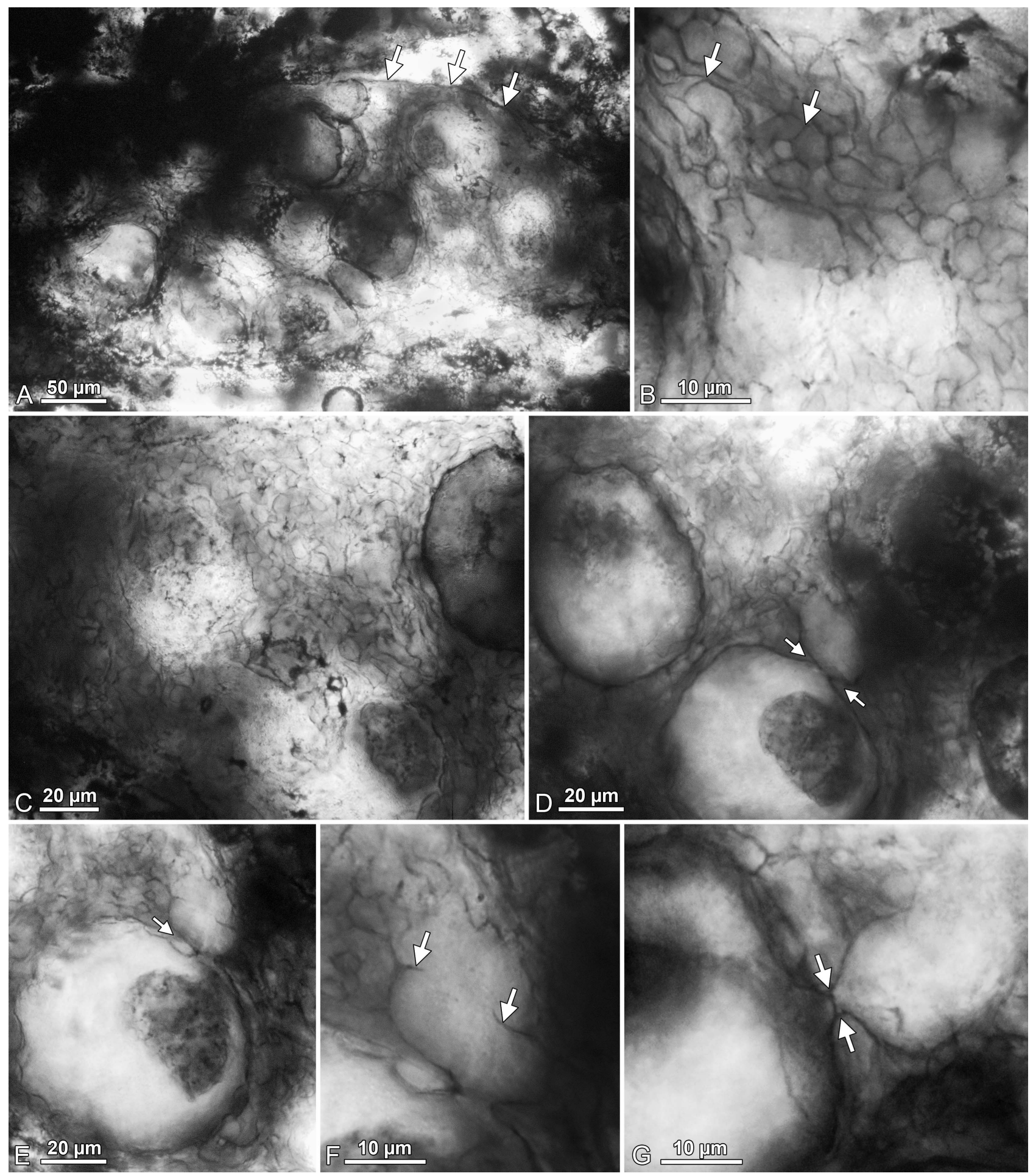

Fig. 2. A-G. Portion of fossil sporocarp from the Middle Triassic of Antarctica. A. Overview; arrows indicate narrow peridium. B. Gleba; arrows indicate septa. C, D. Two focal planes of same area, showing zygosporangia embedded in gleba; arrows in D indicate budding point of one sporangium from gametangium. E. Same sporangium as in D, different focal plane; arrow indicates budding point from gametangium. F. Detail of E, focusing on gametangium; arrows indicate remnants of septum between gametangium and suspensor. G. Septum (?) between gametangium and sporangium (arrows). Slide number: A-G: 26593 (Paleobotany Division, Natural History Museum and Biodiversity Institute, University of Kansas, Lawrence). 
fossil are recognizable. The fossil consists of a spheroidal structure that is borne on an inflated, sac-like structure to which is attached a smaller globose element subtended by a distally widened hypha. The spheroidal structure is $85 \mu \mathrm{m}$ diam and composed of a central cavity surrounded by a prominent investment. The investment is up to $20 \mu \mathrm{m}$ thick, two-layered, with the outer, prominent layer composed of hyphae, and the inner, narrow layer non-hyphal. The central cavity is up to $55 \mu \mathrm{m}$ diam. The contents of the cavity apparently are congealed or denaturated and recognizable as a subcentric accumulation of dark material. The inner, non-hyphal investment layer is recognizable as a narrow dark line $(<1.5 \mu \mathrm{m}$ thick) extending along the inner surface of the hyphal investment; the nonhyphal layer appears to be confluent with the wall of the subtending, sac-like structure (FIG. 1B). The hyphal investment (mantle) is between 10 and $\sim 20 \mu \mathrm{m}$ thick and constructed of a system of irregularly swollen, tightly interlaced hyphae, each 2-8 $\mu \mathrm{m}$ wide. Hyphae are relatively thin-walled and translucent; septa have not been observed. Subtending the mantled spheroid is a prominent, smoothwalled sac-like structure $\sim 70 \mu \mathrm{m}$ long and up to $27 \mu \mathrm{m}$ wide (FIG. 1A arrows); a direct connection exists between the central cavity of the spheroid and the lumen of the sac-like structure (FIG. 1B). The distal portion of the sac-like structure is separated from the rest by a septum (FIG. 1B arrows). Moreover, the distal portion of the sac-like structure is sheathed by the hyphal investment, while the proximal portion apparently is not. Physically connected to the tip region of the sac-like structure is a much smaller globose element, $11 \mu \mathrm{m}$ diam (FIG. 1B), which is subtended by a hypha-like structure distally up to $7 \mu \mathrm{m}$ wide (FIG. 3, left side). The lumina of the globose element and sac-like structure are interconnected. Where the proximal end of the sac-like structure appears to have been (not preserved) occurs a patch $(\sim 100 \times 50 \mu \mathrm{m})$ of a conspicuous meshwork of multibranched, irregularly shaped, tightly interlaced hyphae (FIG. 1C). Moreover, close to J. circumtecta, a second, broadly ellipsoid structure (FIG. 1A, lower right) corresponds in size and morphology to the spheroidal component of J. circumtecta. A sac-like associated structure is not preserved together with this specimen.

Fifteen complete and several fragments of isolated propagules closely resembling the spheroidal component of Jimwhitea circumtecta in size and overall morphology have been found in several thin sections. They occur singly, usually freely in the chert matrix associated with dense accumulations of degraded plant fragments. One specimen, however, appears to be attached to the surface of a larger plant fragment (FIG. 1D). Propagules (FIG. 1D-H) are 60-90 $\mu \mathrm{m}$ diam and composed of a central cavity sheathed by a two-layered investment up to $20 \mu \mathrm{m}$ thick. Because the sections are relatively thick, it is possible to document the structure of the complex, outer, hyphal investment layer of these structures in detail by focussing through the objects (FIG. $1 \mathrm{~F}-\mathrm{H}$ ). The outer investment layer consists of a system of tightly interlaced, aseptate hyphae, each 2-7 $\mu \mathrm{m}$ wide, that are relatively thin-walled and translucent. The inner investment layer is recognizable as a narrow dark line extending along the inner surface of the hyphal investment (FIG. 1D, E, H). Fragments of what appears to be a second non-hyphal wall or wall layer occur along the inner surface of the non-hyphal investment layer in some specimens (e.g. FIG. 1D, arrows). Several of the propagules are associated with single or paired smaller spherical, ovoid or elongate structures (or fragments thereof), each up to $20 \mu \mathrm{m}$ diam (or $25 \mu \mathrm{m}$ long and up to $20 \mu \mathrm{m}$ wide), which sometimes also are sheathed by the hyphal investment (FIG. 1E, arrow). In specimens lacking associated structures, the point of their attachment sometimes still can be seen as an interruption in the non-hyphal investment layer (e.g. FIG. 1H, arrows). The central cavity is empty in most of the propagules (FIG. 1D, H), but in some specimens a subcentrically positioned body of apparently congealed contents (FIG. 1E) occurs.

Also occurring in the chert block is a partially preserved sporocarp (FIG. 2) that is $630 \mu \mathrm{m}$ long and $\sim 200 \mu \mathrm{m}$ high. The sporocarp is bounded on the outside by a narrow peridium (or pseudoperidium) less than $2 \mu \mathrm{m}$ thick that is recognizable in places as a distinct dark line (FIG. 3A, arrows); however, details of peridium structure are not recognizable. The sporocarp contains 12 sporangia/spores, which are embedded in a gleba consisting of interwoven, thinwalled hyphae that are irregularly swollen and 2-8 $\mu \mathrm{m}$ wide. Septa are present in the glebal hyphae (FIG. 2B, arrows) but apparently are relatively rare. The individual sporangia/spores are (sub)globose or ovoid and up to $60 \mu \mathrm{m}$ diam. They are enclosed by a narrow wall that is recognizable as a dark line (FIG. 2D). Some sporangia/spores are surrounded by what appears to be a developing hyphal mantle that is incomplete (i.e. not traceable around the entire sporangium). In some of the sporangia/spores are subcentrically or marginally positioned bodies that apparently consist of the denaturated sporangium/ spore contents (FIG. 2D, E). Several of the sporangia/ spores are physically connected via a narrow constriction (up to $5 \mu \mathrm{m}$ wide) to smaller structures that are irregularly shaped, chiefly elongate and sac-like, and 


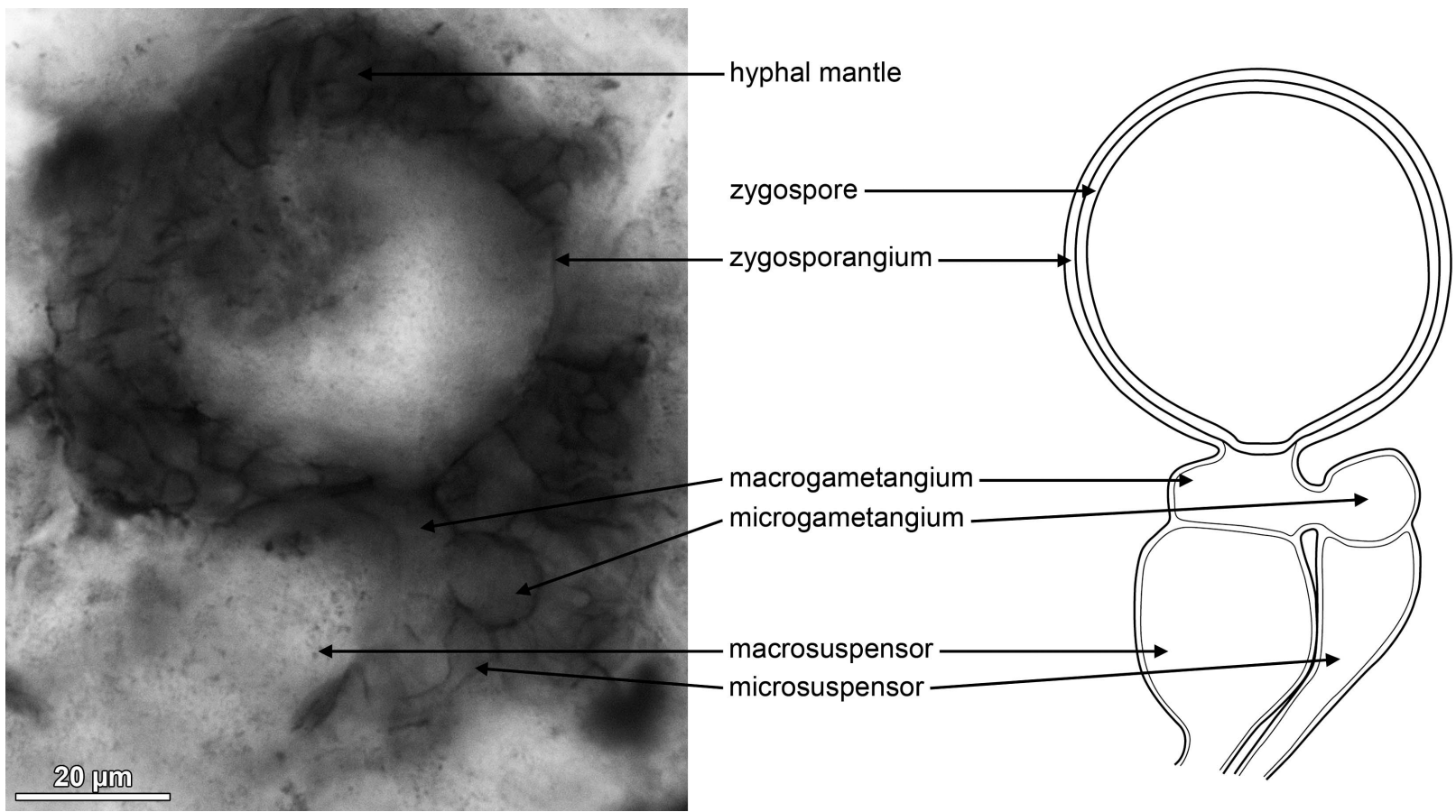

Fig. 3. Comparison of the holotype specimen of Jimwhitea circumtecta gen. et sp. nov. (left side of image; focal plane slightly different from that in FIG. 1A, B) with Thaxter's depiction of a zygosporangium-apposed gametangia complex of Endogone lactiflua (right side of image; redrawn from Thaxter 1922: pl. I, fig. 20).

up to $40 \mu \mathrm{m}$ long and $22 \mu \mathrm{m}$ wide. In most specimens there is no indication of a septum between the sporangium/spore and the associated structure (e.g. FIG. 2F), but in one specimen a septum appears to be present (FIG. 2G, arrows). Several of the associated structures show what appear to be remnants of a septum that in vivo separated the distal portion of the structure from the rest (e.g. FIG. 2F, arrows).

\section{DISCUSSION}

Fossiliferous permineralized peat from the Middle Triassic Fremouw Formation in the central Transantarctic Mountains has been instrumental in our understanding of the morphology and biology of the plants that grew in the early Mesozoic polar ecosystems of Gondwana (Escapa et al. 2011). Fungal remains frequently co-occur with the plants preserved in the peat. However, only a few of these remains have provided information on the precise systematic affinities, nutritional modes and ecology of the fungi (e.g. Stubblefield et al. 1987; Phipps and Taylor 1996; Schwendemann et al. 2009, 2010, 2011). Among the fungal fossils from the Fremouw Formation are several forms interpreted as zygomycetous spores and sporocarps containing spores (Taylor and White 1989; White and Taylor 1989, 1991). These fossils strongly suggest the existence of zygomycetous fungi, order Endogonales, in the Triassic of Antarctica.
None of the fossils, however, reveal the exact configuration of the sexual stage of the life cycle.

Jimwhitea circumtecta.-Jimwhitea circumtecta exhibits a complement of structural features that allows for a direct comparison to structures in modern fungi and thus can be used to assess the biological nature and systematic affinities of the fossil. We interpret $J$. circumtecta as a Triassic representative of the zygomycetous fungi, family Endogonaceae, based on distinct morphological correspondences between the holotype specimen (FIG. 1A, left side of image) and structures formed by certain extant members in the Endogonaceae during sexual reproduction. Especially interesting is a drawing in Thaxter (1922: pl. I, fig. 20) of a structure attributed to Endogone lactiflua Berk. This drawing (reproduced here in FIG. 3, right side) depicts a zygosporangium containing a zygospore budding from a large gametangium (macrogametangium) that is subtended by a macrosuspensor. The macrogametangium, separated from the suspensor by a septum, is fused laterally with a smaller gametangium (microgametangium) that is subtended by a microsuspensor. This configuration in E. lactiflua also has been illustrated by Bucholtz (1912: pl. IV, fig. 36, pl. V, figs. 37, 38, 40, 41, pl. VII, figs. 56, 57, pl. X, fig. 105), Hawker (1954: fig. 1h), and Błaszkowski et al. (2004: fig. 8), among other authors, and similar (developing) zygosporangium-apposed gametangia 
complexes have been observed in other Endogone Link: Fr. species (e.g. Błaszkowski et al. 1998: fig. 5). The configuration depicted by Thaxter for E. lactiflua virtually parallels that seen in J. circumtecta (FIG. 3, left side). As a result, we interpret the spheroidal component of the $J$. circumtecta holotype specimen as a zygosporangium, with the hyphal investment representing the mantle (present also in E. lactiflua [e.g. see Hawker 1954: fig. 1h-k], but for some reason omitted in Thaxter's drawing) and the inner, nonhyphal layer the sporangiothecium (i.e. zygosporangium wall). The prominent, sac-like structure accordingly represents the macrogametangium subtended by a macrosuspensor (with a septum between the two structures; FIG. 1B, arrows), while the small globose element attached to the tip of the sac-like structure would represent the microgametangium subtended by a microsuspensor. If this interpretation is correct, then the meshwork of tightly interlaced hyphae at the proximal end of the macrosuspensor (FIG. 1A, lower left, C) likely represents the gleba that gives rise to the gametangia. Gibson et al. (1986: figs. 5, 6) note that early in the development of the Endogone pisiformis Link zygosporangium, the gametangial septa are convex, whereas in more mature stages these septa are concave. The gametangial septum in J. circumtecta is concave (FIG. 1B, arrows), suggesting that zygosporangium development in the fossil was probably at a more mature developmental stage.

The isolated propagules (FIG. 1D-H) that also occur in the chert block correspond to the spheroidal component of Jimwhitea circumtecta with regard to size and morphology and thus are viewed as representing isolated mantled zygosporangia, in part with gametangia, or remains of gametangia, still attached, of this fungus. Similar structures have been described from the Fremouw Formation and informally named Fungus No. 4 by White and Taylor (1989: pl. II, figs. 4, 5). These fossils have been regarded as Endogone-like spores. An elongate structure attached to one of the specimens illustrated by these authors has been interpreted as a gametangium (White and Taylor 1989: pl. II, fig. 4). The structural correspondences between Fungus No. 4 and J. circumtecta corroborate the hypothesis advanced here that Fungus No. 4 in fact represents an endogonalean sexual reproductive structure.

Despite the many striking similarities between Jimwhitea circumtecta and the zygosporangium-gametangia complexes of certain extant Endogonaceae, there is also one major difference: zygospores are consistently not recognizable in the fossils. The absence of zygospores in the structures interpreted as zygosporangia of $J$. circumtecta challenges the assignment of the fossils to the zygomycetous fungi in general and the Endogonaceae specifically. It is possible, however, that the zygospores (or zygospore walls) simply did not survive the fossilization process intact. On the other hand, the zygospore is thinwalled and it fills the space within the zygosporangium in a way that resulted in the zygospore and zygosporangium walls being so tightly appressed that they cannot be distinguished from one another. Adding some support to the former hypothesis is the presence of what appears to be fragments of a second wall inside the non-hyphal investment layer (i.e. the zygosporangium wall) in several of the isolated zygosporangia (e.g. FIG. 1D, arrows).

Sporocarp.-Two sporocarps containing sporangia/ spores with suggested affinities to the Endogonales have been described from the Triassic of Antarctica and informally named Fungus No. 2 and Fungus No. 3 by White and Taylor (1989: pl. I, fig. 3, pl. II, fig. 1). These sporocarps represent the only evidence to date of sporocarp morphology in fossil zygomycetes. As a result, the sporocarp portion described in this paper represents a highly significant piece of evidence, especially in light of the fact that this specimen is far better preserved and reveals more details about the internal structure and contents of this reproductive structure than the fossils illustrated by White and Taylor (1989). The sporocarp presented in this paper (FIG. 2) differs from both sporocarps described by White and Taylor (1989) with regard to peridium thickness, which is up to $180 \mu \mathrm{m}$ in Fungus No. 2 and up to $90 \mu \mathrm{m}$ in Fungus No. 3, but much thinner (i.e. less than $2 \mu \mathrm{m}$ thick) in our sporocarp (FIG. 2A, arrows). Moreover, a gleba has not been reported in Fungus No. 2 or Fungus No. 3 and the individual spores of Fungus No. 2 are not enveloped in a hyphal mantle.

The sporangia/spores contained in the sporocarp described here concur in size with the zygosporangium of the Jimwhitea circumtecta holotype specimen and the isolated propagules illustrated in FIG. 1D-H, and, therefore, we interpret these structures as zygosporangia. Moreover, several of the zygosporangia in the sporocarp are borne on sac-like structures, which we interpret as gametangia/suspensors (FIG. 2D-G). One of these gametangia shows remnants of a septum separating the distal portion (i.e. the gametangium) from the rest (i.e. the suspensor) (FIG. 2F, arrows), precisely as in the macrogametangium/macrosuspensor of J. circumtecta (FIG. 1B, arrows). Gametangial fusion, however, has not been observed in any of the spores in the sporocarp. In addition, the patch of interlaced hyphae interpreted as a gleba closely associated with the holotype specimen of $J$. circumtecta is structurally similar to the sporocarp gleba (cf. Fig. 1C and Fig. 2B, C). All these correspondences strongly suggest that the 
sporocarp also belongs to J. circumtecta. One difference between $J$. circumtecta and the zygosporangia contained in the sporocarp is the hyphal mantle, which is prominent in the former but hardly recognizable as a distinctive component in the latter fossils. It is possible, however, that the sporocarp was not mature and mantle formation around the individual sporangia was still in an early stage at the time of fossilization. Another interesting feature is a septum that appears to occur between one of the zygosporangia in the sporocarp and its sac-like, subtending gametangium (FIG. 2G, arrows). Hawker (1954: p. 437) notes that in Endogone lactiflua a thin wall delimiting the young zygospore and cutting off the nearly empty gametangium is laid down as soon as most of the contents of the gametangium have passed into the developing zygospore. What appears to be a septum between the gametangium and sporangium might therefore represent a wall separating the developing zygospore from the empty gametangium. In conclusion, the zygosporangia contained in the sporocarp resemble $J$. circumtecta in several key features but we cannot rule out that the sporocarp was produced by a morphologically similar but different species. Thus, we did not include features of the sporocarp in the diagnosis for J. circumtecta.

Systematic position of Jimwhitea circumtecta.-If our interpretation of Jimwhitea circumtecta (FIG. 1A-C) as an endogonaceous zygosporangium with apposed gametangia is correct, then the question arises as to whether the fossil can be more precisely placed within the Endogonaceae based on the morphological features available. The Endogonaceae currently include four genera, Endogone, Peridiospora C.G. Wu et Suh J. Lin, Sclerogone Warcup and Youngiomyces Y.J. Yao (Benny et al. 2001); all of the taxa produce zygospores with apposed gametangia/suspensors in sporocarps (Yao et al. 1996). However, in Endogone the gametangia are joined together with only one attachment site at the zygosporangium base, while in Youngiomyces the gametangial elements are separated by the sporangiothecium between them (Yao et al. 1995). The condition in the fossil corresponds to that seen in Endogone, instead that of Youngiomyces. In Peridiospora, the zygosporangium buds from the top of one of the gametangia (Wu and Lin 1997), as in Endogone (see above) and the fossil J. circumtecta. However, Peridiospora produces unizygosporic sporocarps enclosed in a hyphal peridium while the irregular outline of the hyphal mantle in J. circumtecta, as well as the meshwork of interlaced hyphae (resembling the sporocarp gleba in FIG. 2B, C) and the second zygosporangium associated with the type specimen (FIG. 1A), suggest that zygosporangia in this fossil either were produced in clusters in unstructured masses or in sporocarps. This would explain the assemblage of fossils (FIG. 1A) as representing parts of a dissociated mass or sporocarp. Sclerogone differs from the other taxa in the Endogonaceae in that it produces hard, sclerotioid sporocarps (Warcup 1990, Yao et al. 1996). Unfortunately sporocarp features are not preserved with J. circumtecta. However, if the sporocarp portion (illustrated in FIG. 2) in fact belongs to J. circumtecta, sporocarp features would discriminate J. circumtecta from Sclerogone because the glebal hyphae in the fossil sporocarp are not thickwalled. As a result of these comparisons, J. circumtecta appears to be structurally most similar to Endogone. Based on the preceding, we think that there is sufficient evidence from morphology to assign $J$. circumtecta to the Endogonales, Endogonaceae, with confidence. However, not all features and stages of the life cycle of this fungus are available for comparison with extant representatives; in particular, sporocarp features cannot be unequivocally linked with $J$. circumtecta. We therefore refrain from including J. circumtecta in Endogone, but instead propose a new genus for the fossil.

\section{ConClusions}

The discovery of Jimwhitea circumtecta and the sporocarp portion adds new information to our understanding of the diversity of fungi in the Triassic of Antarctica and thus contributes to a more sharply focused concept of the complexity of early Mesozoic ecosystems. The fossils described in this paper corroborate the hypothesis that at least some of the fossils described by Taylor and White (1989) and White and Taylor $(1989,1991)$ from the Fremouw Formation represent endogonalean sexual reproductive structures. Nevertheless, many more specimens and forms will be necessary to fully assess the paleodiversity of this interesting group of zygomycetous fungi. The fossils described in this paper demonstrate that, with suitable preservation, these organisms can be documented in great detail. Such fossils are also of great importance as a source of information that can be used to accurately calibrate molecular clocks and define minimum ages for various fungal lineages. Moreover, it is becoming apparent that the fossil record of various lineages of fungi is not only ancient but also demonstrates a high diversity of forms, some of which closely parallel extant counterparts, even to details relating to micromorphological features associated with reproduction. Such comparisons now can be used to discuss the evolution of developmental stages of putatively sexual structures in ancient fungi that 
heretofore have not been recognized. This will not only increase our understanding about various groups of fungi in time and space but also when various features evolved.

\section{ACKNOWLEDGMENTS}

National Science Foundation (EAR-0949947 to TNT. and MK) and the Alexander von Humboldt-Foundation (V3.FLF-DEU/1064359 to M.K.) provided financial support. The paper greatly benefited from the constructive comments and suggestions of two anonymous referees.

\section{LITERATURE CITED}

Barrett PJ, Elliot DH. 1973. Reconnaissance geologic map of the Buckley Island Quadrangle, Transantarctic Mountains, Antarctica. US Geol Surv A-3.

$\longrightarrow,-$ Lindsay JF. 1986. The Beacon Supergroup (Devonian-Triassic) and Ferrar Group (Jurassic) in the Beardmore Glacier Area, Antarctica. In: Turner MD, Splettstoesser JD, eds. Geology of the Central Transantarctic Mountains. Washington, D.C.: American Geophysical Union. p 339-428.

Benjamin RK. 1979. Zygomycetes and their spores. In: Kendrick B, ed. The whole fungus. Volume II. The sexual-asexual synthesis [Proceedings of the 2nd International Mycological Conference held at the Environmental Sciences Centre of the University of Calgary Kananaskis, Alberta, Canada]. Ottawa: National Museum of Natural Sciences, National Museums of Canada, and the Kananaskis Foundation. p 573-621.

Benny GL, Hamber RA, Morton JB. 2001. Zygomycota: Zygomycetes. In: McLoughlin DJ, McLoughlin EG, Lemke PE, eds. The Mycota VIIA. Systematics and evolution. Berlin: Springer. p 113-146.

Błaszkowski J, Adamska I, Czerniawska B. 2004. Endogone lactiflua (Zygomycota, Endogonales) occurs in Poland. Acta Soc Bot Pol 73:65-69.

—, Tadych M, Madej T. 1998. Endogone maritima, a new species in the Endogonales from Poland. Mycol Res 102:1096-1100, doi:10.1017/S0953756298006170

Bucholtz F. 1912. Beiträge zur Kenntnis der Gattung Endogone Link. Beih Bot Centralbl, Abt II 29:147-224.

Dotzler N, Taylor TN, Galtier J, Krings M. 2011. Sphenophyllum (Sphenophyllales) leaves colonized by fungi from the Upper Pennsylvanian Grand-Croix cherts of central France. Zitteliana A 51:3-8.

Escapa IH, Taylor EL, Cúneo R, Bomfleur B, Bergene J, Serbet R, Taylor TN. 2011. Triassic floras of Antarctica: plant diversity and distribution in high paleolatitude cummunities. Palaios 26:522-544, doi:10.2110/palo.2010.p10-122r

Farabee MJ, Taylor EL, Taylor TN. 1990. Correlation of Permian and Triassic palynomorph assemblages from the central Transantarctic Mountains, Antarctica. Rev Palaeobot Palynol 65:257-265, doi:10.1016/00346667(90)90075-T

Gibson JL, Kimbrough JW, Benny GL. 1986. Ultrastructural observations on Endogonaceae (Zygomycetes): Endo- gone pisiformis. Mycologia 78:543-553, doi:10.2307/ 3807765

Hammer WR, Collinson JW, Ryan WJ. 1990. A new Triassic vertebrate fauna from Antarctica and its depositional setting. Antarct Sci 2:63-167, doi:10.1017/S0954102090000219

Hawker LE. 1954. British hypogeous fungi. Phil Trans Roy Soc London B 237:429-546, doi:10.1098/rstb.1954.0002

Krings M, Dotzler N, Galtier J, Taylor TN. 2009. Microfungi from the upper Visean (Mississippian) of central France: Chytridiomycota and chytrid-like remains of uncertain affinity. Rev Palaeobot Palynol 156:319-328, doi:10.1016/ j.revpalbo.2009.03.011

—, , Taylor TN, Galtier J. 2007. A microfungal assemblage in Lepidodendron from the Upper Visean (Carboniferous) of central France. CR Palevol 6:431436, doi:10.1016/j.crpv.2007.09.008 2010. A fungal community in plant tissue from the Lower Coal Measures (Langsettian, Lower Pennsylvanian) of Great Britain. Bull Geosci 85:679 690, doi:10.3140/bull.geosci.1209

—_, Taylor TN, Dotzler N, Galtier J. 2011. Fungal remains in cordaite (Cordaitales) leaves from the Upper Pennsylvanian of central France. Bull Geosci 86:777-784, doi:10.3140/bull.geosci.1278

Morton JB, Benny GL. 1990. Revised classification of arbuscular mycorrhizal fungi (Zygomycetes): a new order, Glomales, two new suborders, Glomineae and Gigasporineae, and two new families, Acaulosporaceae and Gigasporaceae, with an emendation of Glomaceae. Mycotaxon 37:471-491.

Osborn JM, Taylor TN. 1989. Palaeofibulus gen. nov., a clamp-bearing fungus from the Triassic of Antarctica. Mycologia 81:622-626, doi:10.2307/3760137

Phipps CJ, Taylor TN. 1996. Mixed arbuscular mycorrhizae from the Triassic of Antarctica. Mycologia 88:707-714, doi: $10.2307 / 3760964$

Schüßler A, Schwarzott D, Walker C. 2001. A new fungal phylum, the Glomeromycota: phylogeny and evolution. Mycol Res 105:1413-1421, doi:10.1017/S0953756201005196

Schwendemann AB, Decombeix AL, Taylor TN, Taylor EL, Krings M. 2011. Morphological and functional stasis in mycorrhizal root nodules as exhibited by a Triassic conifer. Proc Natl Acad Sci USA 108:13630-13634, doi:10.1073/pnas.1110677108

— , Taylor TN, Taylor EL, Krings M. 2010. Organization, anatomy and fungal endophytes of a Triassic conifer embryo. Am J Bot 97:1873-1883, doi:10.3732/ ajb.1000194

$\longrightarrow,-, \longrightarrow$, Dotzler N. 2009. Combresomyces cornifer from the Triassic of Antarctica: evolutionary stasis in the Peronosporomycetes. Rev Palaeobot Palynol 154:1-5, doi:10.1016/j.revpalbo.2008. 11.003

Stubblefield SP, Taylor TN, Trappe JM. 1987. Vesiculararbuscular mycorrhizae from the Triassic of Antarctica. Am J Bot 74:1904-1911, doi:10.2307/2443974

Taylor EL, Taylor TN, Collinson JW. 1989. Depositional setting and paleobotany of Permian and Triassic permineralized peat from the central Transantarctic 
Mountains, Antarctica. Int J Coal Geol 12:657-679, doi:10.1016/0166-5162(89)90068-2

Taylor TN, Galtier J, Axsmith BJ. 1994. Fungi from the Lower Carboniferous of central France. Rev Palaeobot Palynol 83:253-260, doi:10.1016/0034-6667(94) 90073-6

, Klavins SD, Krings M, Taylor EL, Kerp H, Hass H. 2004. Fungi from the Rhynie chert: a view from the dark side. Trans Roy Soc Edinburgh, Earth Sci 94:457-473.

, Krings M, Dotzler N, Galtier J. 2011. The advantage of thin sections over acetate peels in the study of late Paleozoic fungi and other microorganisms. Palaios 26: 239-244, doi:10.2110/palo.2010.p10-131r

, Klavins SD, Taylor EL. 2005. Protoas missouriensis, a complex fossil microfungus revisited. Mycologia 97:725-729, doi:10.3852/mycologia.97.3.725

- Taylor EL, Krings M. 2009. Paleobotany. The biology and evolution of fossil plants. New York: Elsevier/Academic Press Inc. xxi + 1230 p.

, White JF. 1989. Fossil fungi (Endogonaceae) from the Triassic of Antarctica. Am J Bot 76:389-396, doi: $10.2307 / 2444608$

Thaxter R. 1922. A revision of the Endogoneae. Proc Am Acad Art Sci 57:291-351, doi:10.2307/20025921
Warcup JH. 1990. Taxonomy, culture and mycorrhizal associations of some zygosporic Endogonaceae. Mycol Res 94:173-178, doi:10.1016/S0953-7562(09)80609-6

White JF, Taylor TN. 1988. Triassic fungus from Antarctica with possible ascomycetous affinities. Am J Bot 75: 1495-1500, doi: $10.2307 / 2444699$

, -1989 . Triassic fungi with suggested affinities to the Endogonales (Zygomycotina). Rev Palaeobot Palynol 61:53-61, doi:10.1016/0034-6667(89)90061-4

. 1991. Fungal sporocarps from Triassic peat deposits in Antarctica. Rev Palaeobot Palynol 67:229236, doi:10.1016/0034-6667(91)90045-5

White MM, James TJ, O'Donnell K, Cafaro MJ, Tanabe Y, Sugiyama J. 2006. Phylogeny of the Zygomycota based on nuclear ribosomal sequence data. Mycologia 98: 872-884, doi:10.3852/mycologia.98.6.872

Wu CG, Lin SJ. 1997. Endogonales in Taiwan: a new genus with unizygosporic sporocarps and a hyphal mantle. Mycotaxon 64:179-188.

Yao YJ, Pegler DN, Young TWK. 1995. Youngiomyces, a new genus in Endogonales (Zygomycotina). Kew Bull 50: 349-357, doi:10.2307/4110641

— - - 1 1996. Genera of Endogonales. Surrey, England: Royal Botanic Gardens, Kew. 229 p. 